\title{
Zika Virus IgM 25 Months after Symptom Onset, Miami-Dade County, Florida, USA
}

\section{Isabel Griffin, Stacey W. Martin, Marc Fischer, Trudy V. Chambers, Olga L. Kosoy, Cynthia Goldberg, Alyssa Falise, Vanessa Villamil, Olga Ponomareva, Leah D. Gillis, Carina Blackmore, Reynald Jean}

We assessed IgM detection in Zika patients from the 2016 outbreak in Miami-Dade County, Florida, USA. Of those with positive or equivocal IgM after 12-19 months, $87 \%$ $(26 / 30)$ had IgM 6 months later. In a survival analysis, $\approx 76 \%$ had $\operatorname{lgM}$ at 25 months. Zika virus IgM persists for years, complicating serologic diagnosis.

$\mathrm{D}$ iagnosis of Zika virus infection is accomplished by testing for viral RNA or IgM and neutralizing antibodies (1). A cohort study of 62 confirmed Zika virus cases from the 2016 outbreak in Miami-Dade County, Florida, USA, demonstrated that Zika virus IgM remains detectable in most (92\%) persons 12-19 months after symptom onset (2). We estimated the proportion of persons with detectable Zika virus IgM up to 25 months after initial illness onset.

\section{The Study}

We included persons residing in Miami-Dade County who had confirmed Zika virus disease with symptom onset during June-October 2016 and had participated in a previous prospective cohort study (2). Of the original 62 patients, we asked all 57 patients with positive or equivocal Zika virus IgM results at 12-19 months after symptom onset to provide another specimen 6 months later. We obtained written consent for the additional specimen from study participants. We tested all serum specimens at the Centers for Disease Control and Prevention (Fort Collins, Colorado, USA) by the IgM capture ELISA for Zika virus (3-5).

Author affiliations: Florida Department of Health in Miami-Dade County, Miami, Florida, USA (I. Griffin, C. Goldberg, A. Falise,

V. Villamil, O. Ponomareva, R. Jean); Centers for Disease Control and Prevention, Fort Collins, Colorado, USA (S.W. Martin,

M. Fischer, T.V. Chambers, O.L. Kosoy); Bureau of Public Health Laboratories, Miami (L.D. Gillis); Florida Department of Health, Tallahassee, Florida, USA (C. Blackmore)

DOI: https://doi.org/10.3201/eid2512.191022
We used SAS version 9.4 (https://www.sas.com) to manage and analyze the data and performed a nonparametric survival analysis (i.e., PROC ICLIFETEST) for interval-censored data to estimate the duration of Zika virus $\operatorname{IgM}$ detection. For this procedure, we considered survival to be the detection of Zika virus IgM (a positive or equivocal result). We included the IgM results of specimens from all 62 original participants collected 12-19 months after symptom onset and the IgM results from all follow-up specimens acquired in the survival analysis. The Florida Health Institutional Review Board (Tallahassee, Florida, USA) approved this study.

Of 57 persons with positive or equivocal Zika virus IgM results at 12-19 months after symptom onset, 30 $(53 \%)$ provided a follow-up specimen. The median time of specimen collection after symptom onset was 21 (range 18-25) months; 5 (17\%) patients provided a specimen at 18 months after symptom onset, 1 (3\%) at 19 months, $6(20 \%)$ at 20 months, $9(30 \%)$ at 21 months, $3(10 \%)$ at 22 months, $3(10 \%)$ at 23 months, $1(3 \%)$ at 24 months, and $2(7 \%)$ at 25 months.

Demographics and clinical characteristics of the 62 participants in the original study were previously reported (6). Of the 30 who provided an additional follow-up specimen, the median age at symptom onset was 45 (range 2270 ) years; all were adults $>18$ years of age. Fifteen $(50 \%)$ were female, and 14 (47\%) were Hispanic. After reviewing case investigations, we found that $13(43 \%)$ of these participants reported no international travel (outside of the continental United States) during the 2 years before collection of the last specimen.

Of the 30 participants who provided a follow-up specimen, 19 (63\%) were positive for Zika virus IgM, 7 (23\%) had an equivocal result, and 4 (13\%) were IgM seronegative. Compared with results from the specimen collection 6 months earlier, 20 (67\%) remained positive for Zika virus IgM, 2 (7\%) remained Zika virus IgM equivocal, 4 (13\%) transitioned from Zika virus IgM positive to equivocal, and $4(13 \%)$ transitioned from Zika virus IgM equivocal to negative; no participants switched from Zika virus IgM positive to negative. Because of the small sample size, we were unable to assess whether age group, race, or ethnicity was associated with Zika virus IgM results. When we used all available test results from the 62 participants, a survival 




Figure. Estimated proportion of persons with detectable Zika virus IgM up to 25 months after symptom onset among persons with PCR-confirmed Zika virus disease, Miami-Dade County, Florida, USA. Detectable Zika virus IgM was defined as a positive or equivocal result on IgM capture ELISA. Interval-censored nonparametric survival analysis probability estimates and $95 \% \mathrm{Cls}$ (gray boxes) are shown.

analysis indicated that $93 \%$ (95\% CI 82\%-97\%) of participants had detectable (positive or equivocal) Zika virus IgM at 14 months after symptom onset, $91 \%$ (95\% CI 81\%-96\%) at 17 months, $81 \%(95 \% \mathrm{CI} 69 \%-89 \%)$ at 22 months, and $76 \%(95 \%$ CI $57 \%-88 \%)$ at 25 months (Figure).

\section{Conclusions}

Our findings suggest that approximately three quarters of persons with PCR-confirmed symptomatic Zika disease still have detectable IgM at 25 months after initial illness onset. The prolonged detection of IgM after Zika virus infection is consistent with previous findings for related flaviviruses (6-10). Our findings are specific to the Centers for Disease Control and Prevention IgM capture ELISA for Zika virus, which targets the premembrane and envelope glycoproteins; other available IgM serologic assays targeting other Zika virus proteins might not produce comparable findings (3). In addition, these results are only representative of symptomatic Zika cases; whether persons with asymptomatic Zika virus infections exhibit similar Zika virus IgM persistence is unknown. IgM persistence needs to be assessed with other serologic assays for both symptomatic and asymptomatic Zika virus cases to determine the full duration of Zika virus IgM after infection.

\section{Acknowledgments}

The research team would like to thank the Miami-Dade County residents who volunteered their time to participate in this study and gave their serum specimens to help further our knowledge of Zika virus. The authors would also like to acknowledge the work of the dedicated laboratorians, epidemiologists, and phlebotomists at the Centers for Disease Control and Prevention, Bureau of Public Health Laboratories, and Florida Department of Health in Miami-Dade County.

\section{About the Author}

Dr. Griffin is an outbreak epidemiologist at the Florida Department of Health in Miami, Florida, USA. Her primary research interest is emerging infectious diseases.

\section{References}

1. Rabe IB, Staples JE, Villanueva J, Hummel KB, Johnson JA, Rose L, et al.; MTS. Interim guidance for interpretation of Zika virus antibody test results. MMWR Morb Mortal Wkly Rep. 2016;65:543-6. https://doi.org/10.15585/mmwr.mm6521e1

2. Griffin I, Martin SW, Fischer M, Chambers TV, Kosoy O, Falise A, et al. Zika virus IgM detection and neutralizing antibody profiles 12-19 months after illness onset. Emerg Infect Dis. 2019;25:299303. https://doi.org/10.3201/eid2502.181286

3. Martin DA, Muth DA, Brown T, Johnson AJ, Karabatsos N, Roehrig JT. Standardization of immunoglobulin M capture enzyme-linked immunosorbent assays for routine diagnosis of arboviral infections. J Clin Microbiol. 2000;38:1823-6.

4. Lanciotti RS, Kosoy OL, Laven JJ, Velez JO, Lambert AJ, Johnson AJ, et al. Genetic and serologic properties of Zika virus associated with an epidemic, Yap State, Micronesia, 2007. Emerg Infect Dis. 2008;14:1232-9. https://doi.org/10.3201/ eid1408.080287

5. Theel ES, Hata DJ. Diagnostic testing for Zika virus: a postoutbreak update. J Clin Microbiol. 2018;56:e01972-17. https://doi.org/10.1128/JCM.01972-17

6. Prince HE, Tobler LH, Yeh C, Gefter N, Custer B, Busch MP. Persistence of West Nile virus-specific antibodies in viremic blood donors. Clin Vaccine Immunol. 2007;14:1228-30. https://doi.org/ 10.1128/CVI.00233-07

7. Roehrig JT, Nash D, Maldin B, Labowitz A, Martin DA, Lanciotti RS, et al. Persistence of virus-reactive serum immunoglobulin $\mathrm{M}$ antibody in confirmed West Nile virus encephalitis cases. Emerg Infect Dis. 2003;9:376-9. https://doi.org/ 10.3201/eid0903.020531

8. Gibney KB, Edupuganti S, Panella AJ, Kosoy OI, Delorey MJ, Lanciotti RS, et al. Detection of anti-yellow fever virus immunoglobulin $\mathrm{M}$ antibodies at 3-4 years following yellow fever vaccination. Am J Trop Med Hyg. 2012;87:1112-5. https://doi.org/ 10.4269/ajtmh.2012.12-0182

9. Busch MP, Kleinman SH, Tobler LH, Kamel HT, Norris PJ, Walsh I, et al. Virus and antibody dynamics in acute West Nile virus infection. J Infect Dis. 2008;198:984-93. https://doi.org/10.1086/591467

10. Poland JD, Calisher CH, Monath TP, Downs WG, Murphy K. Persistence of neutralizing antibody 30-35 years after immunization with 17D yellow fever vaccine. Bull World Health Organ. 1981;59:895-900.

Address for correspondence: Isabel Griffin, Florida Department of Health in Miami-Dade County, Department of Epidemiology, Disease Control, and Immunization Services, 8175 NW 12th St, Ste 314, Miami, FL 33126, USA; email: griffin.isabel@gmail.com 